\title{
Modern Computer Implementation on Smart Phone with Android Platform for Smes (UMKM) in Optimization Services District Malang
}

\author{
Alexius Endy Budianto, S.Kom, MM., Eris Dianawati, Spd, MM, \\ Faculty Of Information Technology University Kanjuruhan Malang
}

\begin{abstract}
The use of Android in the smartphone operating system currently used by many companies. Because of its superiority as a software that uses computer code base that can be distributed openly (open source) so many applications that can be downloaded by penggguna smartphone without paying the application fee.

Believed to be a smartphone that uses the Android operating system will be less costly than a smartphone that uses the operating system are paid. Then to work the MSME sector businesses is in accordance with the condition of our society, especially people Malang. It only takes a willingness Human Resources who are committed to the implementation of SME businesses and to optimize service thoroughly and consistently.

Keywords: Modern Computer Implementation, Services, SME, Android.
\end{abstract}

\section{Introduction}

In previous studies the authors have designed an e-commerce application to get up with the use of mobile computing technology as an accelerator of small and medium micro enterprises (SMEs) in Malang. This brings a very positive impact on the community of SMEs (UMKM) in Malang, because it can meet the needs of the current by means of marketing a product that is very easy and requires a relatively short time. In connection with lebik good service to consumers who have felt the impact of e-commerce, the writer will be implemented into a smart phone (smartphone) with the Android platform that is currently being developed and used in the community because it is cheap, easy and interesting.

The smart phone is no stranger to the users mobile phone, smart phone (smartphone) is a mobile phone that has a high level of ability, sometimes with a function that resembles a computer. There is no factory standard, defining a smart phone. For some people, the smart phone is a phone that works using the entire operating system software that provides a standard and fundamental relationships for application developers. For others, a smartphone is simply a phone that presents advanced features like e-mail (electronic mail), the Internet and the ability to read electronic books (e-books) or there is a keyboard (either built-in or external) and a VGA connector. In other words, the smart phone is a mini computer which has the capabilities of a phone.

While Android has various advantages as software that uses computer code base that can be distributed openly (open source) so that users can create new applications in it. Google's Android has integrated native application such as push email Gmail, Google Maps, and Google Calendar. The fans then build the open source community to build and share Android-based firmware with a number of adjustments and additional features, such as FLAC lossless audio and the ability to store downloaded applications on the microSD card. They frequently update the firmware packages and combines elements of Android functionality and improve security systems.

SMEs in promoting efforts are required to improve the quality and quantity as well as a convenient service, especially at this time easily found a web site that displays a lot of promos place of business and it is easily accessible via the Android Smartphone. This should be maintained by SMEs (UMKM) if the business will be well developed and certainly could continue to grow if the business unit we can improve the service system is getting better at marketing.

Micro, Small and Medium Enterprises (SMEs) have a crucial role in realizing economic and industrial growth of a country. In Malang economic growth derived from the contribution of SMEs (UMKM). In addition to contributing to the local revenue also contributed to employment opportunities. Where SMEs can absorb quite a lot of labor. Pekonomian conditions globally, requires SMEs (UMKM) to make changes in a comprehensive manner in order to increase their competitiveness.

One of the important factors that will determine the competitiveness of SMEs is to improve services to the public on the implementation of the e-commerce system that can improve business transformation through speed, accuracy and efficiency of the exchange of large amounts of information and improve services to the public and consumers..

In order to keep the service as well as a sustainable competitive advantage with an e-commerce diimplementasinya into android smartphone, it can be formulated as follows: 
1) Modern Computer with Android smartphones will provide business services and performance of SMEs (UMKM) become easier and better.

2) Smartphone android at designated to facilitate access to the internet so it helps in business services.

3) Due to the current android smartphones are multi application, it is very competitive in the business data processing

4) Smartphone android use touchscreen navigation. So much easier to use.

5) In order to apply the appropriate technology.

Modern Computer Implementation of the Smartphone is very important in creating a competitive advantage and improve services in SMEs (UMKM). One of the organization's resources and skills of the most important is that information technology can be a source of sustainable competitive advantage.

\section{Android Operating System Definition}

Android is software for mobile devices that includes an operating system, middleware and key applications. Application development on the Android platform using the Java programming language. A series of core Android applications including an email client, SMS program, calendar, maps, browser, contacts, and others.

By providing an open development platform, Android offers developers the ability to build applications that are extremely rich and innovative. Developers are free to take advantage of the hardware, access location information, run background services, set alarms, add notifications to the status bar, and much more. Android relies on Linux version 2.6 for core system services such as security, memory management, process management, network stack, and driver model. The kernel also acts as an abstraction layer between the hardware and the entire software stack.

\section{Smart Phone (Smartphone)}

There is no agreement in the industry about what makes a phone into a "smart", and the notion of a smart phone that also change with the years. According to David Wood, Executive Vice President of PT Symbian OS, "The smart phone can be distinguished by a regular cell phone with two fundamental ways: how they are made and what they can do." Another notion gives emphasis to the difference of these two factors.

Most tools are categorized as smart phones use different operating systems. In terms of features, most smart phones support the facility fully personalized email with complete control functions. Other functions can include a miniature QWERTY keyboard, touch screen or D-pad, camera, setting a list of names, speed, navigation software and hardware, the ability to read business documents, music player, photo explorer and viewing video clips, internet explorer, or just secure access to corporate email open, such as those offered by BlackBerry. Features are most commonly found in the smart phone is the ability to store a list of names as much as possible, not like a regular cell phone that has a maximum storage limit roster.

\section{Concept Of Transformation Data}

Understanding system data transformation and difference of encode, encrypt and hash. Here the authors try to conclude the difference :

\section{Encoding}

Examples of Character: Base64

S8td0s5NTk / x4kZNHp6Ud9tyjAfQIiOywcFTFay + jfLUSJ9EaKcx4 =

Encodes goal is to change the data so that the data can be used by other systems properly and safely, for example: Can be sent via e-mail or displayed on web pages. This method is not to maintain the confidentiality of information, but rather leads to ensure that the data can be used correctly.

Encode changing data into a different format using a common scheme, so that the data can be easily decoded back. This method does not require a special key to decode the data, it takes is the algorithm used to menencode data.

Example: Base64, ASCII Encryption

Character Example: RSA 


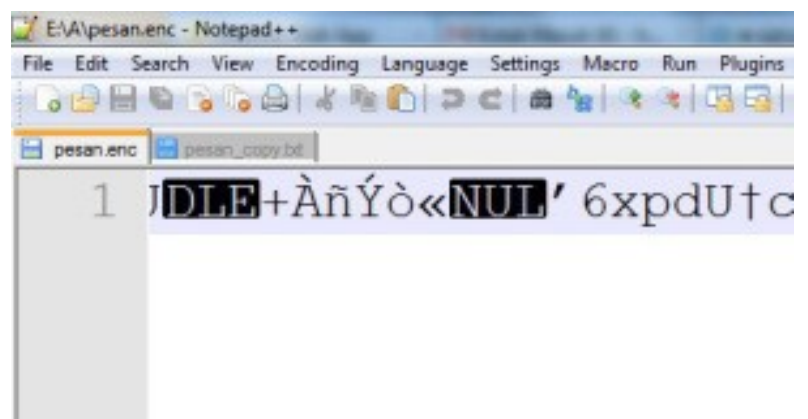

The purpose of encryption is to convert the data that can be kept confidential. suppose to send a secret message that only people - certain people who can read it. This method does not refer to usability (ability to use) but rather refers to the ability to ensure that data can not be used other than those specified.

Encryption change the data into another format by using the scheme (limited) or can be just people certain people who can mereverse / reverse data into text normal form. To open the necessary functions of the cipher text, a specific algorithm and a key.

Example: RSA, AES

\section{Hashing}

Example Character MD5:

e10adc3949ba59abbe56e 057f20f883e

Hashing is often considered to be the same as the encryption method and encode, but in fact these methods differ from each other. The purpose of hashing is to create / add input as 'arbitrary' which will result in a character that has a fixed length and has the following attributes:

1. The same input always produces the same output.

2. Several different input does not have to produce the same output.

3. The method of the path input - output.

4. Any modification of a given input will result in drastic changes to the hash.

Hashing is used in conjunction with authentication to produce strong evidence that a given message has not been modified. This is accomplished by taking a given input, hashing it, and then encrypting the sent hash with the recipient's public key.

Hashing is used in the authentication to generate strong evidence that the data have not changed. This is done by taking a given input, hashing, and then encrypt the hash sent with the recipient's public key.

When the recipient opens the message with Reviews their private keys they then hash the message them- selves and compare it to the hash that was given encrypted by the sender. If they match it is an unmodified message.

When the recipient opens the message with their private key, they then hash the message itself and compare it with the hash that has been given by the sender. If they match it is a message that is not modified.

Example: SHA, MD5

Schematically, the process data into information processing can be described in Figure 1 below:

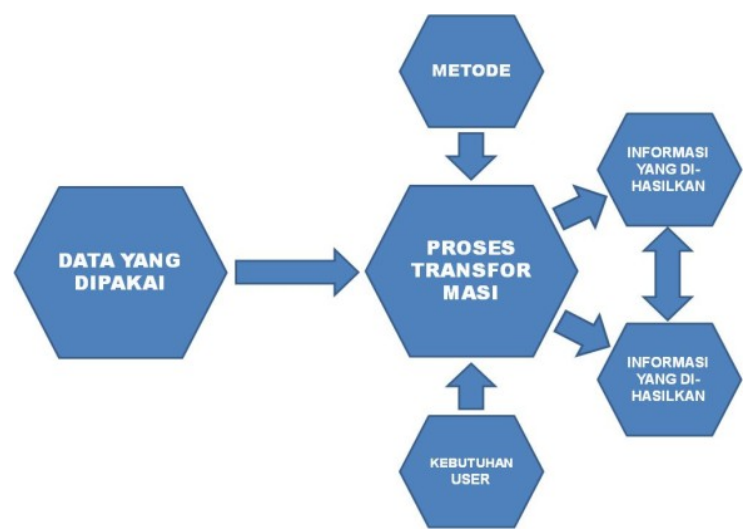

Figure 1 Transformation of data into information 


\section{Planning}

\section{Stages In The System Implementation}

Planning is making all the plans related to the project information system. if we want to build a house then we will do the planning of how the foundation, how the structure of the building, wanted to use any material, what color the walls, not ketinggalakan also planned budget budget we should spend.

\section{Analysis}

Once planning is complete, the next step is to make an analysis (analyst). Analysis is to analyze workflow information systems that are running and identify whether the workflow has been streamlined and fit a certain standard. Analysis conducted by the processs Business Analyst (BPA) is an experienced and / or understand the workflow management system in the area that is being analyzed.

\section{Design}

Once the analysis is complete, the next step is to make the design (desgin). Design is a very important step in the SDLC cycle because this step determines the foundations of information systems. errors in design can create barriers even project failure.

There are 2 types of designs created in this step, the business process design and programming design.

a. Business Process Design

b. Programming design

Design of the programming is done by Systems Analyst (SA) is making the necessary design to programming based design of business processes that have been made by BPA. This design will serve as guidelines for the programmer to write source code.

Design programming include:

1) database design

2) Screen Layout Design

3) Diagram Design Process

4) Design Report Layout

\section{Development}

Work done in the development phase (development) is programming. Programming is a job writing computer programs with algorithms and programming languages based on certain logic. its called the Programmer.

\section{Testing}

There is no ivory that is not cracked, a proverb which means nothing is perfect in the world this. This applies also in man-made information systems. therefore, needs to be a process to test the quality of information systems.

This process is commonly called testing.

Testing is a process that is designed as such to identify mismatches result an information system with the expected results.

\section{Implementation}

Implementation is the process to implement the information system has been built to allow users to use it to replace the old information system.

Implementation Process:



\section{Operation and Maintenance}

Most final step is the operation and maintenance. during the operation of information systems, there are several pekerjaa routine that needs to be done on information systems, among others:
a. system Maintenance
b. Backup \& Recovery
c. Data Archive 


\section{Research Objectives}

Objectives can be achieved in this study are as follows:

1. Implementation of Computer Modern Smartphone with Android platform in order to better optimize the service to the SME (UMKM) community in Malang.

2. Provide information about the utilization of Android smartphones in the Business World, especially SMEs.

3. Identify the various issues related to the Business World SmartPhone Utilization.

4. Develop Android applications to improve the utilization SmartPhone For Business Media.

5. Provide insight and learning in SmartPhone for business use.

\section{Research Methods}

In accordance with the background and the problems encountered and solutions to existing problems researchers used data processing is used to support the results of this study were obtained through interviews (interviews), observation and documentation with a view to the implementation of a modern computer with the use of a smartphone with android (SMEs) in Malang.

\section{Location Research}

In accordance with the background, problem definition and formulation of the problem and the purpose of the research study site in accordance with previous studies which are SMEs (UMKM) region Malang (Malang particular)

\section{Object Research}

SMEs in Malang

Modern Computer Implementation In order SmartPhone With Android Platform Optimization Services

\section{Population}

The study population was all SMEs (UMKM) that exist in Malang Data collection techniques and sample Data collection techniques were used to support the results of this study were obtained through interviews (interviews), observation and documentation. Sampling technique in this study using purposive sampling technique.

\section{System Implementation}

The procedure is performed untukmenyelesaikan designs that are in the approved system design documentation and test, install, start, and use the new system or system maintenance. The use of computers in solving problems requires a good system to generate a good solution in the process data into information.

\section{Analysis of data}

Analysis of data is done via data tabulation data collection results are then used for comparative analysis of Modern Computer Implementation In order SmartPhone With Android Platform Optimization Services SMEs (UMKM) in Malang

\section{The study design}

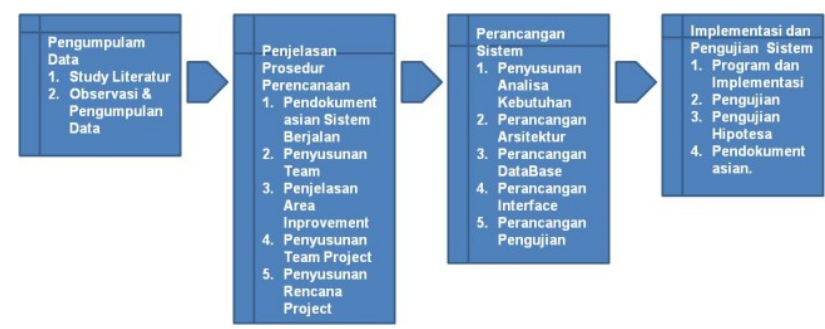

Figure 2 Flow Research Methodology

\section{Using Black Box Testing}

System testing is done to check the compactness or performance between components in a system that has been implemented. The main purpose of the testing system is to ensure that the elements or components of the system is functioning in accordance with what is expected by the author. 
Testing methods are taken black box testing methods. Black box testing is a fundamental aspect of testing the system without regard to the internal logic structure of software. This method is used to determine whether the software is functioning properly.

Black box testing is a method of test data design is based on software specifications. The data in the test on the software and then output to check whether the software in accordance with the expected or not.

\section{Testing the Main Menu}

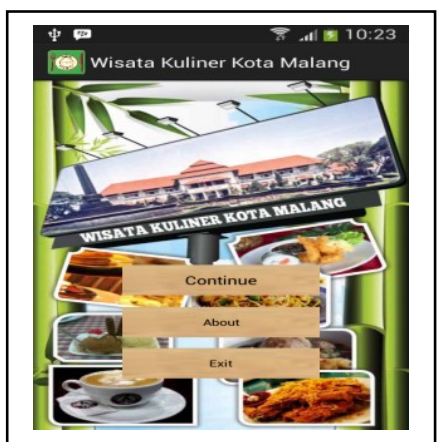

Pictures Main Menu

In the figure, shows the design of the interface on the main page of the application system culinary Malang. The main menu page design itself consists of a continue button, about and exit, the continue button to proceed to the page selanjutnnya the category menu page, the button is about to proceed to about page and exit button to exit the application.

Table. Testing Process Main Menu

\begin{tabular}{|l|l|l|l|l|l|}
\hline No & \multicolumn{1}{|c|}{ The need } & \multicolumn{1}{|c|}{ Description } & Expected Results & Real results & \multicolumn{1}{|c|}{$\begin{array}{l}\text { Testing } \\
\text { Results }\end{array}$} \\
\hline 1. & $\begin{array}{l}\text { Continue to test the } \\
\text { function button on the } \\
\text { main menu }\end{array}$ & $\begin{array}{l}\text { Select the } \\
\text { continue button }\end{array}$ & $\begin{array}{l}\text { Open a new page that } \\
\text { culinary category } \\
\text { page }\end{array}$ & $\begin{array}{l}\text { Can access the } \\
\text { page } \\
\text { corresponding to } \\
\text { the continue } \\
\text { button function }\end{array}$ & $\begin{array}{l}\text { In } \\
\text { accordance }\end{array}$ \\
\hline 2. & $\begin{array}{l}\text { Test the function button } \\
\text { on the main menu about }\end{array}$ & $\begin{array}{l}\text { Select button } \\
\text { about }\end{array}$ & $\begin{array}{l}\text { Opening a new page } \\
\text { is the page about the } \\
\text { application }\end{array}$ & $\begin{array}{l}\text { Can access the } \\
\text { page } \\
\text { corresponding to } \\
\text { the function } \\
\text { button about }\end{array}$ & $\begin{array}{l}\text { In } \\
\text { accordance }\end{array}$ \\
\hline 3. & $\begin{array}{l}\text { Test the exit button } \\
\text { function on the main } \\
\text { menu }\end{array}$ & $\begin{array}{l}\text { Select button } \\
\text { about }\end{array}$ & exit the application & $\begin{array}{l}\text { Can exit the } \\
\text { application }\end{array}$ & $\begin{array}{l}\text { In } \\
\text { accordance }\end{array}$ \\
\hline
\end{tabular}

\subsubsection{About Testing Process}



Picture Pages About 
Interface design on the page displays information about the application about culinary tourism. Starting from the application name, version of the application, the application icon image, and application developers / developer

Table Process Testing About Page

\begin{tabular}{|l|l|l|l|l|l|}
\hline No & The need & \multicolumn{1}{|c|}{ Description } & Expected Results & Real results & $\begin{array}{l}\text { Testing } \\
\text { Results }\end{array}$ \\
\hline 1. & About the test & $\begin{array}{l}\text { Users select the } \\
\text { button on the } \\
\text { menu about } \\
\text { culinary }\end{array}$ & $\begin{array}{l}\text { Displays a new page } \\
\text { containing the } \\
\text { application about the } \\
\text { name, version, } \\
\text { application icon and } \\
\text { application } \\
\text { developers. }\end{array}$ & $\begin{array}{l}\text { Can display a new } \\
\text { page as expected }\end{array}$ & $\begin{array}{l}\text { In } \\
\text { accordance }\end{array}$ \\
\hline
\end{tabular}



Testing Process Category Culinary



Interface design on this culinary category menu page displays five culinary categories consisting of fried chicken category / grilled, meatballs, noodles, cafe n restaurant and culinary past, there is also a culinary Malang maps that will show the location of the overall culinary Malang. Each category will display a page culinary culinary sub categories consisting of 5 restaurants. 
Table Process Testing Menu Category Culinary

\begin{tabular}{|l|l|l|l|l|l|}
\hline \multirow{2}{*}{ No } & \multicolumn{1}{|c|}{ The need } & \multicolumn{1}{|c|}{ Description } & Expected Results & Real results & $\begin{array}{l}\text { Testing } \\
\text { Results }\end{array}$ \\
\hline 1. & $\begin{array}{l}\text { Test function category } \\
\text { list chicken, meatballs, } \\
\text { noodles, cafe } \mathrm{n} \\
\text { restaurant, culinary } \\
\text { past. }\end{array}$ & $\begin{array}{l}\text { Select the category } \\
\text { list chicken, } \\
\text { meatballs, noodles, } \\
\text { cafe n restaurant, } \\
\text { culinary past }\end{array}$ & $\begin{array}{l}\text { The new page } \\
\text { displays the sub } \\
\text { category pages of } \\
\text { each category }\end{array}$ & $\begin{array}{l}\text { Can access the page } \\
\text { corresponding to } \\
\text { each list }\end{array}$ & $\begin{array}{l}\text { In } \\
\text { accordance }\end{array}$ \\
\hline
\end{tabular}

\section{Testing In Sub Category Fried Chicken / Fuel}

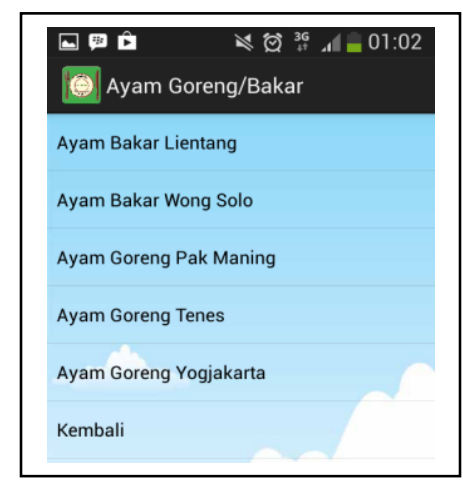

Picture Page Menu Sub Categories Fried Chicken / Fuel

Interface design on the sub category pages chicken fried / grilled consisting of the 5 restaurants, restaurant lientang grilled chicken, grilled chicken wong solo, maning pack fried chicken, fried chicken Tenes, fried chicken and Yogyakarta

Testing Process Maps

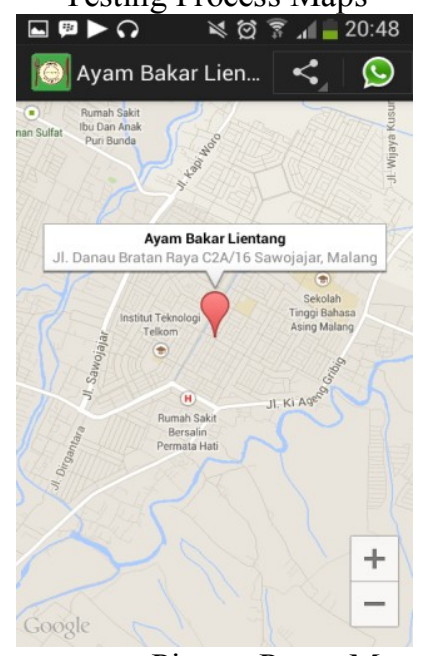

Picture Pages Maps

Interface design on the maps page showing the location of grilled chicken lientang map using google maps, and marked with a marker that if user press it will display the restaurant name and address information.

Table Testing Process Maps Page

\begin{tabular}{|l|l|l|l|l|}
\hline \multirow{2}{*}{ No } & \multicolumn{1}{|c|}{ The need } & \multicolumn{1}{|c|}{ Description } & Expected Results & Real results \\
\hline 1. & Test the process maps & $\begin{array}{l}\text { Users select the } \\
\text { maps in the list } \\
\text { option menu }\end{array}$ & $\begin{array}{l}\text { The system displays a } \\
\text { new page that is the } \\
\text { location of the restaurant } \\
\text { on google maps }\end{array}$ & $\begin{array}{l}\text { Can display the } \\
\text { location of the } \\
\text { restaurant on google } \\
\text { maps }\end{array}$ \\
\hline
\end{tabular}




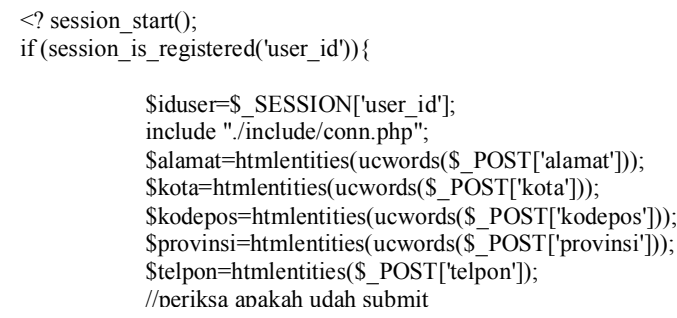

\section{Konclusion}

Based on the description and analysis, then the conclusion can be drawn as follows:

1. Based Android Smartphone app can help SMEs (UMKM) and users in determining where culinary according to user desires in Malang in particular.

2. This application provides information about culinary in the city of Malang. Making it easier for SMEs (UMKM) and Users for a culinary tour of the city of Malang.

3. With this application, will add to the travelers who come to the city of Malang.

\section{Suggestion}

Advice from the author for this android Smartphone-based application will feel perfect if any of my friends who want to develop this simple application. Like google maps methods that can be developed for user Reviews directions, ie displays Reviews directions from the user to the location of the restaurant.

\section{References}

[1]. Android.2012. http://id.wikipedia.org/wiki /Android_(sistem_operasi). Diunduh: 19 Juli 2013, Pukul 14.23

[2]. Bagus Handoko, Haryo. 2009. Buku Tempat Makan Makanan Favorit di Malang. Malang: Gramedia.

[3]. Haryanto, Agus. 2013. Belajar Android Menampilkan Map dengan Android Google Maps API V2. http://agusharyanto.net. Diunduh: 24 Agustus 2013

[4]. Huda, Arif Akbar. 2012. 24 JAM !!! Pintar Pemrograman Android. Yogjakarta: Andi Offset

[5]. Michael Siregar, Ivan. 2011. Membongkar Source Code berbagai Aplikasi Android. Bandung: Gava Media.

[6]. Safaat H, Nazruddin. 2012. Pemrograman Aplikasi Mobile Smartphone dan Tablet PC Berbasis Android (edisi revisi). Bandung: Informatika.

[7]. Tyas. 2013. Pengertian UML. http://informatika.web.id/ pengertian-uml.htm. Diunduh: 12 Januari 2014

[8]. Tjetjep Rohendi Rohidi). London : Sage Publishing.

[9]. Moleong, Lexy.J. (1989). Metodologi Penelitian kualitatif. Bandung : P.T. Rosda Karya.

[10]. Nogroho, Bunafit. 2008. Sistem Informasi Berbasis Web dengan PHP dan MySQL. Penerbit Gava Media, Jakarta. 